\title{
THE APPLICABILITY OF CO-COMBUSTION OF COAL WITH SEWAGE SLUDGE: A REVIEW
}

\author{
S. Camera ${ }^{a}$, \\ T. Pineda-Vásquez ${ }^{\mathrm{a}}$, \\ F. M. Bianchi ${ }^{\mathbf{b}}$, \\ E. Virmond ${ }^{a}$, \\ L. S. Martins ${ }^{c}$, \\ and E. S. Watzko ${ }^{\mathrm{a}}$ \\ ${ }^{a}$ Universidade Federal de Santa Catarina \\ Programa de Pós-Graduação em Energia e \\ Sustentabilidade \\ Rua Pedro João Pereira, 150, Mato Alto \\ Araranguá, Santa Catarina, Brasil \\ sabrinas.camera@gmail.com \\ latatiss@gmail.com \\ elaine.virmond@ufsc.br \\ elise.sommer@ufsc.br \\ ${ }^{\mathrm{b}}$ Faculdade SATC \\ Centro Tecnológico SATC \\ Rua Pascoal Meller, 73, Bairro Universitário, \\ Criciúma, Santa Catarina, Brasil \\ flavio.bianchi@satc.edu.br \\ 'Univesidade Federal do Paraná \\ Programa de Pós-Graduação em Engenharia e \\ Ciência de Materiais \\ CEP 81531-990 - Curitiba, PR, Brazil \\ lauber@ufpr.br
}

\section{ABSTRACT}

Co-combustion of coal with a secondary fuel, as for example, wastebiomass, including sewage sludge, isan option for its safe its elimination and a sustainable alternative for heat and power generation. Untreated sewage sludge has a negative impact on the environment and society due to its compositional and pathogenic factors. Co-combustion of coal and sewage sludge have advantages over some emissions parameters and improvement of thermal characteristics, but there are limiting factors for its large-scale use, especially regarding to the fuel feed which requiresinnovative methods to develop a product that combinesboth fuels. When it comes to environmental impact, the combined combustion of and coal with sewage sludge presents good opportunities for future research and technological applications to be explored. This review focuses on the combination of coal and sewage sludge, highlighting the possibilities and limitations of the co-combustion using them as fuel.

Keywords:co-combustion; sewage sludge; coal

Received: March 14, 2020

Revised: April 21, 2020

Accepted: May 28, 2020

\section{NOMENCLATURE}

$\mathrm{CO}_{2}$ carbone dioxide

$\mathrm{N}_{2} \quad$ nitrogen

$\mathrm{NO}_{\mathrm{x}}$ nitrogen oxides

$\mathrm{O}_{2}$ oxigen

$\mathrm{SO}_{2}$ sulfur dioxide

$\mathrm{SO}_{\mathrm{x}}$ sulfur oxides

\section{INTRODUCTION}

The capability of generating and distributing energy is paramount for the economic and social development of a nation. Due to the low and stable price of the fuel, and therefore, the economic viability, the combustion of coal is still the most common way of power generation.

The world production of coal had an increase of
1.5\% in 2019. There was also an increase of its use for electricity generation of $3.3 \%$ in 2018, when compared to 2017. China is the largest consumer of coal in the world followed by India. Even though coal is used largely around the world, there is an international effort in favor of the decarbonization of the electric power sector driven specially by the European Union and United States (IEA, 2020).

The Brazilian National Energy Balance of 2019 showed that $54.7 \%$ of the energy needed to move the economy is from non-renewable energy sources, from which $5.8 \%$ is from coal(Brasil, 2019). The gas emissions of the combustion from coal has significant amount of pollutants as for example, sulfur dioxide and nitrogen oxides.

The sewage sludge from water treatment plants is nowadays an environmental issue since it also has high concentration of organic pollutants and metals. 
However, the combustion of the sewage sludge combined with coal can release a significant amount of energy in a renewable way.

As aforementioned, environmental and social issues stimulated the search for optimum processes of using coal with the least possible impact in the society and the environment. The co-combustion with the sewage sludge has promising results specially by addressing another relevant matter, the disposal of the sludge. The goal of this study is, through a literature review, to present the environmental and social impacts of the use of coal and sewage sludge as fuel, discuss the co-combustion based on techniques already used for other materials considering the limiting factors of the process.

\section{ALTERNATIVES TO CO-COMBUSTION OF COAL}

The coal from Brazilian mines haslower heating values and high levels of sulfur and ash when compared to the coal from other countries, therefore, it is seen as a low quality coal. That points towards co-combustion as a way to better release the chemical energy of the fuel.

We can also combine the combustion of coal with crude glycerol by the synthesis of pallets or briquettes, which results in an increase of heating value and reduction of ash.(Costa et al., 2017; Lu et al., 2014; Whittaker e Shield, 2017).

The combustion of biomass combined with coal reduces greenhouse gases emissions from coal power plant.It also reduces $\mathrm{CO}_{2}$ emission of the electric sector, which considers it neutral. (Więckolryk e Smoliński, 2017).

Studies performed by Atimtay (2009) on fluidized bed combustors reveal that lignite coals can have co-combustion with agro-waste. The agrowaste used were peach stone, apricot stones and olive cake produced from the olive oil industry. The study suggests that the percentage of the peach and apricot stones in the mixture must be below $50 \%$ and demonstrates that the co-combustion produces low $\mathrm{SO}_{2}$ emissions.

Byproducts of the production of biodiesel can be used in the co-combustion of coal. According to Lee et al. (2016), coal impregnated with glycerol had an increased in the specific heat and in the combustibility at low and high temperature up to $20 \%$ of glycerol of content.Lee et al. (2016) also states that hybrid coalcan be produced using bioliquid matter, which is obtained from molasses. In this case, the coal is crushed and mixed with the bio-liquid matter (molasses). Bae et al. (2014) say that in cases where the porous of the coal are impregnated with the glycerol, the hybrid coal presents higher content of carbon and hydrogen when compared to raw coal and also presents a single combustion behavior.

Co-combustion of coal with sewage sludge has become an attractive alternative since it is not seen only as a burning process but an energy conversion process generating useful heat.

The sewage sludge biomass can be energetically mixed with coal and transformed in pellets. Sewage sludge has its energetic potential enhanced when mixed with anthracite or lignite coal.(Kijo-kleczkowska et al., 2016).

The co-combustion of coal with sewage sludge in a circulating fluidized bed is another way of burning coal (Leckner et al., 2004). This kind of cocombustion promote better interaction between the molecules of the fuel and the oxygen in the air.

The study of co-combustion of coal and biomass has shown improvement, however models for solid urban waste have not been researched much therefore, theyneed to be investigated in more depth (Jiang et al., 2017).

\section{SOCIO AND ENVIRONMENTAL ASPECTS OF THE PRODUCTION AND USE OF COAL AND SEWAGE SLUDGE}

Since the Industrial Revolution, at the end of the XVIII century, the development of the civilizations has been founded on the use of nonrenewable energy sources; coal at first and later on, oil. The emission of pollutants to the atmosphere is a consequence of the use of such energy sources (Virmond, 2007).

It is common knowledge that $\mathrm{CO}_{2}$ is one of the emissions of the combustion of coal and is also responsible for greenhouse effect and climate change.

Mining and coal combustion, if not performed appropriately, cause severe damage to the environment and to the community by contaminating water resources close to the mines. Nonetheless, coal is still an important energy source part of the energy matrix of a number of countries. That fact makes the demand for alternative forms of energyand the optimization of coal combustion for reduced emissions to increasing.

According to Aguirre-Villegas e Benson (2017), coal will continue to be demanded around the world and the environmental impacts of its use must be discussed.

Data from the Department of Nacional Mine Production (DNPM, 2010) point out that the carboniferous resource in Brazil are of the order of 32 billion of tons. Coal is mainly used to generate electricity and from the environmental point of view, it is responsible for the sulfur oxide $\left(\mathrm{SO}_{\mathrm{x}}\right)$ and nitrogen oxide $\left(\mathrm{NO}_{\mathrm{x}}\right)$ emissions. The co-combustion of coal with sewage sludge using catalysts like $\mathrm{Ce}$ and $\mathrm{Fe}$ shows reduction on the emission of the pollutants aforementioned(Wang et al., 2018).

Other than environmental impact of leaching and the volatilization of metals, Munawer (2018) 
studied the damages of the mono-combustion of coal to human health. The author found out that depending on the composition and form (wet and dry) of the fly ash, it can cause bone deformity and kidney dysfunction.

Due to its environmental impact and effects in the human health, the production and disposal of sewage sludge is a concerning subject among people and government from different countries.

The environmental impact of the increasing production of sewage sludge has been so severe in Poland that the government changed the legislation imposing more restrictions, including the ones regarding its storage (Kijo-Kleczkowska et al., 2016).

The production of sewage sludge is proportional to population growth. Studies point out that in 2050, the production of this residual biomass in Brazil will be 0.8 million of tonnes of oil equivalent, representing an increase of $69 \%(\mathrm{EPE}$, 2018).

The sewage sludge from the treatment of municipal waters is extremely harmful to human health since it may contain organic compounds and pathogens in high concentration. A recent study published by Fongaro et al. (2020) detected SARSCoV-2 in samples collected from sewage drains. That just reinforces the need of treatment and adequate disposal of the urban waste.

The sewage sludge hasalso applications in agriculture. However, there are laws regulating reduction of pathogens and content of sulfur, nickel and lead for that use (Brasil, 2006; Zhang et al., 2017).

The sewage sludge may be transferred to landfills, however a large amount of impermeable land far away from urban areas is necessary. There will be leaching, gases will be generated and the recovery land process after the landfill is closed is slow and difficult (Lee, 2011). We emphasize the possibility of using the sewage sludge transferred to the landfill as an energy source.

When we take into consideration issues related to greenhouse emissions, the sewage sludge can be an option to reduce $\mathrm{CO}_{2}$ emissions, since its biomass is considered carbon neutral fuel (Kijo-Kleczkowska et al., 2016).

Several authors, as we have been documenting in this study, agree that the sewage sludge has a negative impact on the environment and the nearby community either where it is generated or disposed, not only because of contaminants but also due to odours that comes from it. The co-combustion of sewage sludge reduces significantly its volumeand its characteristic odours.Another advantage is the fact that under co-combustion condition, the sewage sludge reduces the amount of the other fuel used, which in most of the cases are non-renewable (KijoKleczkowska et al., 2016).

Due to the composition and properties of the sewage sludge, it is required that the gases generated by its combustion aremonitored, controlled and treated(Kijo-Kleczkowska et al., 2016).

\section{OPERATIONAL CONDITIONS}

The operational conditions are extremely relevant for a co-combustion process to be feasible. Variables as moisture, the percentage of each component of the mixture and additives, for example, must be carefully considered with much attention in order to obtain the results that meet the expected emissions and efficiency of the system.

The key point to be considered when selecting an energy conversion technology is the property of the fuel. Depending on the characteristics of the conversion, the co-combustion of coal with biomass may not be adequate for a specific application, either because of technical or environmental reasons. The source of the fuel also plays a role in its properties (Virmond et al., 2013).

Limestone is used as an additive when the cocombustion occurs in a fluidized bed, which improves the emission of the conversion. According to Lupiáñez et al. (2016), there was an increase of $\mathrm{NO}_{\mathrm{x}}$ emissions for the co-combustion of lignite coal with limestone. That could be an issue when the biomass presents a higher content of nitrogen higher than the coal and are subject to and high levels of oxygen.

Co-combustion requires some specific requirements. The heating value of the primary fuel must be higher than the heating values of the secondary fuel, for example. According to Ninduangdee andKuprianov (2018), the secondary fuel should have lower nitrogen content than the primary one in order to avoid oxide of nitrogen formation.

Experimental research has shown that sewage sludge with moisture content up to $10 \%$ mixed with anthracite coal in a $50 \%$ proportion, reduced the ignition time, increased the volatile combustion time, decreased the combustion time in relation to mono-combustion of pure coal (Kijo-Kleczkowska et al., 2016).

The moisture content of the primary and secondary fuel is not only relevant for the combustion profile but also for storage purposes. If the moisture content is higher than $10 \%$, odours and the increase of biological activities may be an issue. That would lead to an increase of temperature of the storage. The combustion of the fuel will be affected by the high content of moisture since part of the energy generated will be spent to evaporate the water.

In some countries of the Europe Union there is an emission limit for sludge energy faction of less than 25\%, except for chlorine emissions (Leckner et al., 2004).

A high content of nitrogen, metals and 
moisture in the sludge when compared to the coal have effect on the reactions during the thermochemical conversion. That raises technical challenges for its practical applications (SyedHassan et al., 2017), which must be further investigated.

\section{PERSPECTIVES ON CO-COMBUSTION OF COAL AND SEWAGE SLUDGE}

The availability and energy security of coal, the trend of an increasing sewage sludge production, the need to reduce the use of non-renewable energy sources and the environmental consequences of its emissions has made co-combustion of coal and sewage sludge a very attractive for a safe elimination of this waste and its incorporation to energy scenario.

The co-combustion of two or more fuels with different proprieties is effective regarding the reduction of emission of a combustion system without reducing the efficiency of the combustion itself (Ninduangdee e Kuprianov, 2018). However, the behavior of the mixture must be studied in order to evaluate the influence of mixture properties on the overall performance of the process.

The percentage of each fuel may influence the emissions and the economic viability of the implementation and maintenance of the strategy.

One of the biggest challenges of the combined use of coal and sewage sludge is the development of a single fuel or mixture that can be fed to the combustors in an effective way without the need of big financial investments in the set up that already exists.

One of the most common ways of transporting the fuel for the combined combustion present challenges to control the dosage and homogeneity of the mixture.

The use of the mixture in pellets form is an alternative that is already in use with other combinations of biomass and coal (KijoKleczkowska et al., 2016).

Experiments performed with glycerol and molasse are showing promising results for the development of hybrid coal with sewage sludge. In this case, the sludge could be used in a liquid form to promote its impregnation in the porous of the coal. Even though promising, there is still need to research more about the method of production and properties of this combined fuel

\section{CONCLUSIONS}

The use of coal is indeed essential to meet the energy need of the world population, however, it must be done in a responsible way looking for alternatives to improve the combustion process and reduce its environmental and social impact.
The sewage sludge has been shown positives and promising results in co-combustion in combination with coal. However, innovative techniques for production of a fuel derived from the mixture of these two fuels (hybrid coal) must be developed. Therefore, there is a lot to explore until the application of the combination of these fuels are wide spread.

\section{ACKNOWLEDGEMENTS}

The authors would like to thank the support of the Coordenação de Aperfeiçoamento de Pessoal de Nível Superior (CAPES).

\section{REFERNCES}

Aguirre-Villegas, H. A., and Benson, C. H., 2017, Case History of Environmental Impacts of an Indonesian Coal Supply Chain, Journal of Cleaner Production, Vol. 157, pp.47-56.

Atimtay, A. T., 2009, Combustion of Agro-Waste with Coal in a Fluidized bed, Clean Technologies and Environmental Policy, Vol. 12, pp.43-52.

Bae, J., et al., 2014, Production of the GlycerolImpregnated Hybrid Coal and its Characterization, Fuel - Elsevier BV, Vol. 118, pp. 33-40.

Costa, S. C., et al., 2017, Solid Biofuel from Glycerol and Agricultural Waste as Source of Energy, Cellulose Chemistry and Technology, pp. 765-774.

DNPM - Departamento Nacional de Produção Mineral (BRASIL), 2000, Informativo Anual da Indústria Carbonífera 2000 (ano base 1999), DNPM, Brasília. (in Portuguese)

EPE, 2018, Papel da Biomassa na Expansão da Geração de Energia Elétrica: documento de Apoio ao PNE 2050, MME. (in Portuguese)

Fongaro, G. et al, 2020, SARS-CoV-2 in Human Sewage in Santa Catalina, Brazil, MedRxiv, pp. 1-11.

Gug, J. et al., 2015, Processing and Properties of a Solid Energy Fuel from Municipal Solid Waste (MSW) and Recycled Plastics, Waste Management, Vol. 35, pp. 283-292.

Huaman, R. N. E., and Jun, T. X., 2014, Energy related CO2 Emissions and the Progress on CCS Projects: a Review, Renewable and Sustainable Energy Reviews, Vol. 31, pp. 368-385.

IEA, 2020, Coal Information: Overview, Paris.

Jiang, X., 2017, Models for the Combustion of Single Solid Fuel Particles in Fluidized Beds: a Review, Renewable and Sustainable Energy Review, pp. 410-431.

Kijo-Kleczkowska, A. et al., 2016, Experimental Research of Sewage Sludge with coal and Biomass Co-Combustion, in Pellet Form, Waste Management, Vol. 53, pp. 165-181.

Leckner, B. Et al., 2004, Gaseous Emissions 
from Co-Combustion of Sewage Sludge and Coal/Woodin a Fluidized Bed, Fuel, Vol. 83, pp.477486.

Lee, B., et al., 2016, Combustion Behavior of Low-Rank Coal Impregnated with Glycerol, Biomass and Bioenergy - Elsevier BV, Vol. 87, pp. 122-130.

Lee, E. S. H., and Santos, F. J., 2011, Caracterização do lodo proveniente de Estação de Tratamento de Esgoto (ETE) e Estudo sobre seu Potencial Energético, in: Congresso Brasileiro de Gestão Ambiental, Londrina. Anais Congresso Brasileiro de Gestão Ambiental. (in Portuguese)

Lu, D., et al., 2014, Experimental Trials to Make Wheat Straw Pellets with Wood Residue and Binders, Biomass and Bioenergy - Elsevier BV, Vol. 69, pp. 287-296.

Lupiáñez, C. et al., 2016, The Role of Limestone during Fluidized bed Oxy-Combustion of Coal and Biomass, Applied Energy, Vol. 184, pp.670-680.

Munawer, M. E., 2018, Human Health and Environmental Impacts of Coal Combustion and Post-Combustion Wastes, Journal of Sustainable Mining, Vol. 17, pp.87-96.

Ninduangdee, P., and Kuprianov, V. I., 2018, Fluidized Bed Co-Combustion Of Rice Husk Pellets and Moisturized Rice Husk: the Effects of CoCombustion Methods on Gaseous Emissions, Biomass and Bioenergy, Vol. 112, pp. 73-84.

Syed-Hassan, S. A. et al., 2017, Thermochemical Processing of Sewage Sludge to Energy and Fuel: fundamentals, Challenges and Considerations, Renewable and Sustainable Energy Reviews, Vol. 80, pp. 888-913.

Virmond, E., et al., 2013, Valorization of Agroindustrial Solid Residues and Residues from Biofuel Production Chains by Thermochemical Conversion: a Review, citing Brazil as a Case Study, Brazilian Journal of Chemical Engineering, Vol. 30, pp. 197-230.

Virmond, E., 2007, Aproveitamento do lodo de Tratamento Primário de Efluentes de um Frigorífico como Fonte de Energia, Master Thesis, Programa de Pós-Graduação em Engenharia Química - UFSC, Florianópolis, SC. (in Portuguese)

Wang, Z. et al., 2018, Combustion Behaviors and Kinetics of Sewage Sludge Blended with Pulverized Coal: with and without Catalysts, Waste Management, Vol. 74, pp. 288-296.

Whittaker, C., and Shield, I., 2017, Factors Affecting Wood, Energy Grass and Straw Pellet Durability: a Review, Renewable and Sustainable Energy Reviews - Elsevier BV, Vol. 71, pp.1-11.

Więckol-ryk, A., and Smoliński, S., 2017, CoFiring Coal and Biomass Blends and their Influence on the Post-Combustion $\mathrm{CO}_{2}$ capture Installation, in: E3S Web of Conferences, Issn. 2267-1242.

Zhang, Q. et al., 2017, Sludge Treatment: Current Research Trends, Bioresource Technology, Vol. 243, pp. 1159-1172. 